\title{
A COMPARISON OF ARTIFICIAL NEURAL NETWORK MODELS AND REGRESSION MODELS TO PREDICT TREE VOLUMES FOR CRIMEAN BLACK PINE TREES IN CANKIRI FORESTS
}

\author{
USPOREDBA MODELA UMJETNE NEURALNE MREŽE ZA \\ PREDVIĐANJE DRVNOG VOLUMENA KRIMSKIH BOROVA \\ U ŠUMAMA POKRAJINE CANKIRI
}

Muammer ŞENYURT* ${ }^{*}$ ilker ERCANLI

\begin{abstract}
In this study, it is aimed to use and compare Artificial Neural Network (ANN) models for predicting individual tree volumes for of Crimean Black Pine trees within the Cankiri Forests. The single and double entry-volume equations and the Fang et al. (2000)'s compatible volume equation based on the classical and traditional methods were used by 360 Crimean Black Pine trees to obtain these tree volume predictions. To determine the best predictive alternative for ANN models, a total of 320 trained networks in the Multilayer Perceptron (MLP) and a total of 20 trained networks in the Radial Basis Function (RBF) architectures was trained and used to obtain the individual tree volume predictions. On the basis of the goodness-of-fit statistics, the ANN-based on MLP 1-9-1 including dbh as an input variable for single entry volume predictions showed a better fitting ability with SSE (2.7763), (0.9339), MSE (0.00910), RMSE (0.0954), AIC (-823.25) and SBC (-1421.81) than that by the other studied volume methods including dbh as an explanatory variable. For double entry volume predictions, including dbh and total height as input variables, ANN based on MLP 2-15-1 resulted in better fitting statistics with SSE (0.8354), (0.9801), MSE (0.00274), RMSE (0.0523), AIC (-579.55) and SBC (-1788.11).
\end{abstract}

KEY WORDS: Tree Volume Prediction, Artificial Neural Network, Single and double volume equations, Segmented taper equation

\section{INTRODUCTION}

\section{UVOD}

The individual tree volume predictions have been a principal objective of forest inventory studies and these predictions require both the sustainable planning of forest resour- ces and for the estimations of the forest biomass and carbon stocks (Wiant et. al., 1992; Avery and Burkhart, 2002). Since foresters have a wide part of being aware of the primary importance of volume predictions for forest practices such as sustainable resource management and timber harvesting operations, forest managers have spent many efforts for de-

\footnotetext{
* Assistant Profesor Muammer Şenyurt, Assistant Profesor Ilker Ercanli, Çankırı Karatekin University, Forestry Faculty 18200 ÇANKIRI, TURKEY, E-mail: msenyurt@karatekin.edu.tr
} 
veloping the individual volume methods and models that could be combined with other forest simulators in forest operations (Clutter et al. 1983; van Laar and Akça 2007).

As the individual trees have no recognizable geometric shape, such as a cylinder, paraboloid, cone, and neyloid, it is not possible to directly calculate tree volume using analytical methods without falling tree. The unique practical solution to this inventory procedure, including felling tree that can be a time consuming and costly operation is the use of allometric relationships between the individual tree volume and other tree attributes such as diameter at breast height, dbh, and height that could be easily and practically measured in forest inventory and could be dendrometrically correlated with the tree volume. These allometric models are statistical equations that can be used to estimate the stem volume or commercial volume of a tree from certain independent variables such as diameter at breast height (dbh) or total height. When included the dbh as independent variables, these equations are called as "Single Entry Tree Volume Equations, while the equations comprised together the dbh and height are called as "Double Entry Tree Volume Equations". In addition, the equations prepared based on three or more variables such as $\mathrm{dbh}$, tree height and stem diameter at a certain point on a tree (e.g. at $30 \%$ of the tree length) or trunk diameter at 7 meters above the ground is called as "Multiple Entry Tree Volume Equations".

Because of this practical usability of the volume equations in forest inventory, numerous volume equations have been presented and developed by using the statistical techniques in forestry literature over the past several decades. However, these single or double entry volume equations cannot predict the tree volume to any merchantable height or diameter limits and become impracticable to produce the predictions for tree volume by assortments of tree log sizes if stem merchantable standard alter in the forest stand harvesting and yield operations (Reed and Green 1984; Gal and Bella 1995). Alternatively, the stem taper equations that can provide the predictions of diameter at any height of the stem, the height to any specific diameter, merchantable volume and merchantable height to any top diameter and ant stump diameter can be used to obtain the total individual tree volume predictions. Although there are two major categories of taper equations, the segmented polynomial taper equations that were firstly represented by Max and Burhart (1976) has been regarded to most precise for predicting the individual tree volume to any merchantable limits (Jiang et al. 2005). Max and Burhart (1976), Clark et al. (1991), Fang et al. (2000), Jiang et al. (2005) developed the segmented polynomial taper and compatible volume equations that predicted individual tree volume by basing on this compatible taper equation.
While developing these single or double entry volume equations and taper-based equations, the tree data that collected through individual tree measurements are fitted by using the Linear Regression Analysis or Nonlinear Regression Analysis, which are subject to statistical methods. However, these linear or nonlinear equations developed through regression analysis methods can provide accurate and reliable estimations only if certain statistical fundamental assumptions have been assured, which can be listed as a normal distribution of model errors, homogeneity of error variances, no correlation between errors (autocorrelation), and no correlation between independent variables (multicollinearity). Recently, Artificial Neural Networks (ANNs) have gained prominence in the area of forest biometricians, since such networks are able to provide successful predictions without any requirement for the assumptions of statistical assumptions. Artificial Neural Networks (ANNs) are widely used in the estimation-based processes of several fields of engineering, such as aircraft, automobiles, electronics, production, robotics, communications, and civil engineering. ANNs can be a very useful tool in engineering practices and can be a strong tool in data modeling (Esteban et al. 2009; Atkinson and Tatnall 1997; Ashraf et al. 2013; Buğday 2018; Doğan and Buğday 2018). However, there are only a limited number of studies on the use of ANN in the forest applications about modeling individual tree volume predictions. Diamantopolou et al. (2005), Diamantopolou (2006), Özçelik et al. (2010), Soares et. al. (2011), Görgens et al. (2009), Silva et al. (2009), Binoti et al., (2014), Bhering et al. (2015), Miguel et al. (2016) and Sanquetta et al. (2018) found the best predictive volume by using ANN with respect to other prediction methods. In addition to these studies, it is particularly necessary to conduct more studies on artificial neural networks that can be defined as a member of artificial intelligence and ANN as the new technique may probably provide an opportunity to obtain more accurate and predictive volume predictions in the field of forestry beyond classical regression models. Thus, the objectives of the present study are (1) to develop Artificial Neural Network Models for predicting of individual tree volumes of Crimean Black Pine trees within the Çankırı Forests and (2) to evaluate various ANN having different neuron contents and transfer functions for the volume predictions with the single and double entry volume equations and Fang et al. (2000)'s compatible volume equation.

\section{MATERIAL AND METHOD MATERIJAL I METODA}

In this study, 360 tree samples that were selected from different diameters and heights to reflect the variability in volume were used to model the individual tree volume of 
Table 1. Summary statistics for sample trees

Tabela 1. Ukupna statistika za uzorke drveća

\begin{tabular}{|c|c|c|c|c|c|c|}
\hline & & $\begin{array}{l}\text { Number of trees } \\
\text { Broj stabala }\end{array}$ & $\begin{array}{l}\text { Min. } \\
\text { Min }\end{array}$ & $\begin{array}{l}\text { Max. } \\
\text { Max }\end{array}$ & $\begin{array}{c}\text { Mean } \\
\text { Aritmetička sredina }\end{array}$ & $\begin{array}{c}\text { Std. Deviation } \\
\text { Standardna } \\
\text { devijacija }\end{array}$ \\
\hline \multirow{3}{*}{$\begin{array}{c}\text { Modeling Data } \\
\text { Modeliranje } \\
\text { podataka }\end{array}$} & $\begin{array}{c}\mathrm{dbh}(\mathrm{cm}) \\
\text { Prsni promjer }(\mathrm{cm})\end{array}$ & & 4.0 & 50.3 & 24.6 & 10.0 \\
\hline & $\begin{array}{l}\text { Height }(m) \\
\text { Visina }(m)\end{array}$ & 306 & 3.8 & 18.7 & 11.7 & 2.6 \\
\hline & $\begin{array}{l}\text { Volume }\left(\mathrm{m}^{3}\right) \\
\text { Volumen }\left(\mathrm{m}^{3}\right)\end{array}$ & & 0.0046 & 2.0203 & 0.4077 & 0.3717 \\
\hline \multirow{3}{*}{$\begin{array}{l}\text { Validation Data } \\
\text { Podaci o provjeri } \\
\text { valjanosti }\end{array}$} & $\begin{array}{c}\mathrm{dbh}(\mathrm{cm}) \\
\text { Prsni promjer }(\mathrm{cm})\end{array}$ & 54 & 5.0 & 52.1 & 29.0 & 13.6 \\
\hline & $\begin{array}{l}\text { Height }(m) \\
\text { Visina }(m)\end{array}$ & & 5.7 & 18.7 & 12.1 & 2.9 \\
\hline & $\begin{array}{l}\text { Volume }\left(\mathrm{m}^{3}\right) \\
\text { Svezak }\left(\mathrm{m}^{3}\right)\end{array}$ & & 0.0065 & 1.8343 & 0.6414 & 0.5539 \\
\hline
\end{tabular}

Crimean Black Pine trees of Cankiri Forests located in Cankiri and Sarıkaya Planning Units, Cankiri Forest Enterprise, Ankara Forest District Directorate. Sample trees were cut at the bottom log height $(0.3 \mathrm{~m})$, and the stump diameter was measured at 0.3 meters, then other measurements were made as precisely as possible at 1-meter intervals ( $1.3 \mathrm{~m}, 2.3 \mathrm{~m}, 3.3 \mathrm{~m}$ etc.) using a steel measuring tape. Furthermore, the total heights of the trees were also measured with a steel measuring tape. During these measurements, in cases where the tree trunks were oddly shaped, not cylindrical, two vertical cross-sectional diameters were measured, and their average was taken into consideration. The sample trees were randomly split into two data sets, the modeling and the validation data sets, using the random number function RANUNI implemented in the SAS statistical package (Statistical Analysis System [SAS Institute], 2009). Of those, about $85 \%$ (306 sample trees) were used to train ANN models and fit the single and double entry volume equations and Fang et al. (2000)'s compatible volume equation, and the remaining 54 sample trees were reserved for the evaluation of the validation and testing. The summary statistics, such as the mean, standard deviations, minimum and maximum for $\mathrm{dbh}$, height, and volume attributes used for modeling and validation data set, are given in Table 1. Figure 1 illustrates the diameter at breast height - volume relations of the sample trees for model fitting and validation data set.

Based on these data, three-segment volumes (bottom log, sections, and top) were calculated for each sample tree, and the sum of these values provided the total stem volume. The bottom log was assumed to be cylindrical, while the top segment was accepted to have a cone-shape. As the section lengths were the same, Huber's equation was used to define the volume of each section. The equations used to calculate tree volumes are given below.
Bottom log volume; Vbottom $=\frac{\pi}{4} \cdot d_{0.3}^{2} \cdot 0.3$

Huber formula for sections;

$$
\text { Vsection }=\frac{\pi}{4} \cdot\left(d_{1.3}^{2}+\cdots+d_{n}^{2}\right) \cdot 2
$$

Top segment; Vtop $=\frac{1}{3} \cdot \frac{\pi}{4} \cdot d_{t o p}^{2} \cdot h_{t o p}$
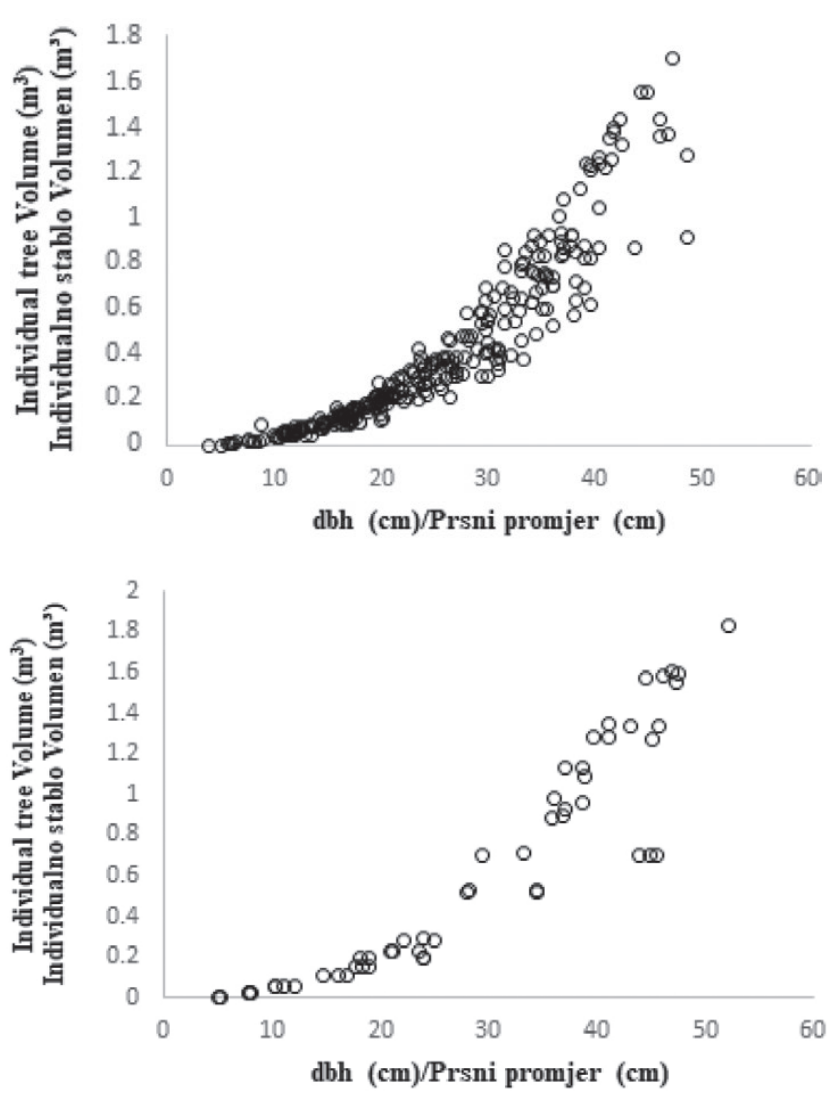

Figure 1. The relationships between individual tree volume and $\mathrm{dbh}$ for modeling (a) and validation data set (b).

Slika 1. Odnos između pojedinih drvnih volumena i dbh za set modela (a) i podataka za vrednovanje (b) 


\section{Single and Double Entry Volume Equations - Jenoulazne i dvoulazne volumne jednadžbe}

To develop single and double entry volume equations predicting the relationships between individual tree volume and dbh and total height, some nonlinear regression models were used in this study. These single and double entry volume equations were developed by using the nonlinear regression analysis, including the total tree volume as the dependent variable and dbh for single entry equation and $\mathrm{dbh}$ and total height for the double entry equation as the independent variables. This linear regression analysis was performed by using PROC MODEL procedure of the SAS/ETS V9 software. In regression analyses, these nonlinear models that provided better predictive volume values than other equations were used to obtain the individual tree volume predictions:

The single-entry volume equation: $V=b_{0} \cdot d b h^{b_{1}}$

The double-entry volume equation: $V=b_{0} \cdot\left(d b h^{2} \cdot h\right)$

\section{Taper-based volume predictions - Volumna predviđanja temeljena na konusu (taper-based)}

From various taper equations, Fang et al. (2000)'s equation presented better predictive results for modeling individual tree taper and compatible volume in many studies (Diéguez Aranda et al. 2006; Corral-Rivas et al. 2007; Crecente-Campo et al. 2009; Pompa et al. 2009; Li and Weiskittel 2010; Tang et al. 2016). In this study, the taper equation of Fang et al. (2000) was fitted to obtain the individual taper-based tree volume predictions and compared with the predictions obtained from the volume equations and ANN models. Fang et al. (2000) presented the segmented taper equation that assumes three sections with a variable-form factor (CorralRivas et al. 2007). Fang et al. (2000)'s stem taper equation is as follows:

$$
d=c_{1}\left[H^{\left(k-b_{1}\right) / b_{1}}(1-g)^{(k-\beta) / \beta} \alpha_{1}^{l_{1}+l_{2}} \alpha_{2}^{L_{2}}\right]^{0.5}
$$

Where $\quad k=\frac{\pi}{40000}$

$$
\begin{aligned}
& g=h / H \quad\left\{\begin{array}{l}
I_{1} \text { if } p_{1} \leq g \leq p_{2} ; 0 \text { otherwise } \| \\
\left.I_{2} \text { if } p_{2} \leq g \leq p_{2} ; 0 \text { otherwise }\right\}
\end{array}\right\} \\
& p_{1}=h_{1} / H \quad p_{2}=h_{2} / H \\
& \beta=b_{1}{ }^{1-\left(l_{1}+l_{2}\right)} b_{2}^{l_{1}} b_{3}{ }^{l_{2}} \quad \alpha_{1}=\left(1-p_{1}\right)^{\left(b_{2}-b_{1}\right) k / b_{1} b_{2}} \\
& \alpha_{2}=\left(1-p_{2}\right)^{\left(b_{3}-b_{2}\right) k / b_{2} b_{3}} \\
& r_{0}=((1-0.3) / H)^{k / b_{1}} \quad r_{1}=\left(1-p_{1}\right)^{k / b_{1}}
\end{aligned}
$$

$$
\begin{aligned}
& r_{2}=\left(1-p_{2}\right)^{k / b_{2}} \\
& c_{1}=\sqrt{\frac{a_{1} D^{a_{2}} H^{a_{3}-k / b_{1}}}{b_{1}\left(r_{0}-r_{1}\right)+b_{2}\left(r_{1}-\alpha_{1} r_{2}\right)+b_{3}\left(\alpha_{1} r_{2}\right)}}
\end{aligned}
$$

Where, d: stem diameter over bark $(\mathrm{cm})$ at a height $\mathrm{h}(\mathrm{m})$, $\mathrm{D}$ : diameter at breast height over bark $(\mathrm{cm})$, h: measuring the height $(\mathrm{m}), \mathrm{H}$ : total height $(\mathrm{m}), \mathrm{p}_{1}$ and $\mathrm{p}_{2}$ are relative heights from ground level in the two inflection points, $\mathrm{a}_{1}$, $a_{2}, a_{3}, b_{1}, b_{2}, b_{3}, c_{1}$ are the equation parameters to be predicted by nonlinear regression. Fang et al. (2000) integrated its segmented taper equation to obtain compatible total volume equation. This compatible volume equation is as follows:

$$
V=a_{0} d b h^{a_{1}} h^{a_{2}}
$$

The prediction of the parameters of this segmented taper equation of Fang et al. (2000) was obtained by using the PROC MODEL.

\section{Artificial Neural Network Models - Modeli umjetne neuronske mreže}

Within the scope of this study, the predictions of individual tree volumes were obtained by using Artificial Neural Network (ANN) models. ANN is a mathematical modeling method inspired by biological neural systems, such as the human brain, and the estimations of ANN is created using computer software, developed according to the physiology of the human brain (Gurney 1999; Demuth and Beale 2001). The artificial neural network model comprises layers with structurally connected nerves. Essentially, these layers are classified as the input layer, the hidden layer and the output layer (Kurup and Dudani 2002). These layers cover artificial neurons called process elements. As a result of their structure, composed of multiple non-linear artificial neurons that can be organized as several layers and work coordinately, they are very successful in solving nonlinear complex problems and creating estimations (Nasr et al. 2003). For ANN, miscellaneous neural structures, input, and output (target) variables in the system to be estimated are defined; then, using these definitions, ANN analyses the data and presents weight values to provide the best possible estimations with minimum error (Fausett 1994). In ANN literature, this process is called network training. ANN is used to provide several different weight values and using these values the output estimations are obtained through the addition and activation functions. Using the estimation values obtained through ANN, the change of errors calculated are analyzed, based on the observation values of the output variable defined in the first place, and the process is complete when the errors reach a minimum level and the error-related changes have reached a fixed point (Fausett 1994; Demuth and Beale 2001). 
In this study, Artificial Neural Network models were evaluated as an alternative method to predict the individual tree volume by using diameter at breast height and a total height of trees as explanatory variables. This neural network model building involved some training, verification and testing process by randomly total sample plots partitioning into training ( $75 \%$ of all data), verification ( $15 \%$ of all data) and test (the remaining $10 \%$ of all data) data. Various computer software applications have been developed to operate the ANN process and present estimations, the STATISTICA ${ }^{\circ}$ software was selected to train the ANN models because this software provides multiple comparisons for different ANN structures, including various network architectures, a number of neurons and activation function in the input, hidden and output layers. When developing these network models, a total of 320 trained networks in the Multilayer Perceptron (MLP) and a total of 20 trained networks in the Radial Basis Function (RBF) architectures were trained and used to obtain the individual tree volume predictions. For those aiming, in ANNs training process with MLP, the number of neurons of the input layer ranged from 1 to 20 neurons options, four activation functions, e.g. identity, logistic, tansig, and exponential functions, in the hidden layer, correspondingly four activation functions in output layer were used (20X4X4=320 alternatives; 20 : number of neurons, 4 : number of transfer functions in the hidden layer and 4 : number of transfer functions in the output layer). In RBF, the number of neurons of the input layer ranged from 1 to 20 neurons options, the hidden layer has the activation function as being on the isotropic Gaussian basis and identity function was used in the output layer. MLP includes a feedforward neural network architecture based on the input, hidden and output layers with a bias term. In MLP, the training algorithm is Broyden-Fletcher-Goldfarb-Shanno (BFGS), which is a robust training algorithm with very fast convergence with the Hessian matrix.

\section{Comparison Criteria - Kriteriji za usporedbu}

After the individual tree volume predictions were obtained by these three methods, including the single and double volume equations, the Fang et al. (2000)'s compatible volume equation and ANN models, these three volume prediction methods were compared by using some evaluation criteria based on the magnitudes and distributions of predictions' residual. These evaluation criteria are some goodness-of-fit statistics including the sum of squared errors (SSE), Akaike's information criterion (AIC), Schwarz Bayesian criterion (SBC), Root Mean Square Error (RMSE), Mean Squared Error (MSE) and Adjusted Coefficient of Determination $\left(\mathrm{R}_{\text {adj }}^{2}\right)$. In these criteria, it is desirable for the SSE, MSE, RMSE, AIC, and SBC to have a small value as possible, while the $\mathrm{R}_{\text {adj }}^{2}$ is expected as close as possible to 1 . The formulae for these statistical values are provided below:
Mean squared errors (MSE) $=\sum_{i=1}^{n} \frac{\left(V_{i}-\widehat{V}_{1}\right)^{2}}{n-p}$

Root mean squared error $($ RMSE $)=\sqrt{\sum_{i=1}^{n} \frac{\left(V_{i}-\widehat{V}_{1}\right)^{2}}{n-p}}$

The Sum of Squared error (SSE) $=\sum_{i=1}^{n}\left(V_{i}-\widehat{V}_{1}\right)^{2}$

Adjusted coefficient of determination

$$
\begin{gathered}
\left(\mathrm{R}_{\mathrm{adj} .}^{2}\right)=1-\frac{\sum_{i=1}^{n}\left(V_{i}-\widehat{V}_{1}\right)^{2}(\mathrm{n}-1)}{\sum_{i=1}^{n}\left(V_{i}-\widehat{V}_{1}\right)^{2}(\mathrm{n}-\mathrm{p})} \\
A I C=n \cdot \ln \left(\frac{S S E}{n}\right)+2 \cdot p \\
S B C=n \cdot \ln \left(\frac{S S E}{n}\right)+p \cdot \ln (n)
\end{gathered}
$$

In these formulae listed above; represents the calculated volume; represents the estimated volume, represents average volume, $n$ represents the number of data and $p$ represents the number of parameters within the model.

To further evaluate these network models, the independent data, including 54 sample trees were used in predicting the tree volume values that were not included in training neural networks. These evaluations were performed by analysis of the difference (residual values) between observed and predicted values for validation data set, 54 sample trees. The t-paired test was used to evaluate the null hypothesis of mean prediction residuals equal to zero. If the null hypothesis tested by $\mathrm{t}$-paired test revealed that the null hypothesis could not be rejected and mean residuals statistically not significantly different from zero, these ANN models were applicable for predicting tree volume values based on the $\mathrm{dbh}$ and height variables in studied forest stands.

\section{RESULTS \\ REZULTATI}

In this study, the prediction methods including single and double entry volume equations, the Fang (2000)'s compatible volume equation and artificial neural network models were used to obtain the individual tree volume predictions. The parameter estimates with probability levels for the single and double volume equations and the segmented taper equation of Fang et al. (2000) are given in Table 2. All parameters of estimates for these nonlinear models were found to be significant at the 0.05 level $(\mathrm{p}<0.05)$. The predicted single and double-entry volume equations and Fang et al. (2000)'s volume equations are as follow:

The single-entry volume equation:

$$
V=0.000203 \cdot d b h^{2.2985}
$$

The double-entry volume equation:

$$
V=0.000448 \cdot\left(d b h^{2} \cdot h\right)
$$


Table 2. The parameter estimates with probability levels and the goodness-of-fit statistics for the single and double volume equations and the segmented taper equation of Fang et al. (2000)

Tabela 2. Parametarske procjene s razinama vjerojatnosti i goodness-of-fit statistikom za jenoulazne i dvoulazne volumne jednadžbe i segmentiranu konusnu jednadžbu (Fang et al. 2000).

\begin{tabular}{|c|c|c|c|c|c|}
\hline $\begin{array}{l}\text { Model } \\
\text { Model }\end{array}$ & $\begin{array}{l}\text { Parameters } \\
\text { parametri }\end{array}$ & $\begin{array}{l}\text { Estimate } \\
\text { Procjena }\end{array}$ & $\begin{array}{c}\text { Standard error } \\
\text { Standardna pogreška }\end{array}$ & $\begin{array}{c}\mathrm{t} \text { value } \\
\mathrm{t} \text { vrijednost }\end{array}$ & $\operatorname{Pr}>|t|$ \\
\hline \multirow{2}{*}{$\begin{array}{l}\text { Single entry volume equation } \\
\text { Jednoulazna volumna jednadžba }\end{array}$} & $b_{0}$ & 0.000203 & 0.0000164 & 12.34 & $<0.0001$ \\
\hline & $b_{1}$ & 2.2985 & 0.02582 & 0.98 & $<0.0001$ \\
\hline \multirow[t]{3}{*}{$\begin{array}{l}\text { Double entry volume equation } \\
\text { Dvoulazna volumna jednadžba }\end{array}$} & $b_{0}$ & 0.0000448 & 0.00000038 & 116.54 & $<0.0001$ \\
\hline & $a_{0}$ & 0.00004 & 0.0000024 & 16.42 & $<0.0001$ \\
\hline & $a_{1}$ & 1.922847 & 0.0153 & 125.85 & $<0.0001$ \\
\hline \multirow{6}{*}{$\begin{array}{l}\text { The segmented taper equation } \\
\text { of Fang et al. (2000) } \\
\text { Segmentirana konusna jednadžba } \\
\text { (Fang et al. 2000). }\end{array}$} & $a_{2}$ & 1.097805 & 0.0284 & 38.70 & $<0.0001$ \\
\hline & $b_{0}$ & 0.000018 & 0.000029 & 5.94 & $<0.0001$ \\
\hline & $b_{1}$ & 0.000036 & 0.00000032 & 109.10 & $<0.0001$ \\
\hline & $b_{2}$ & 0.00003 & 0.00000069 & 43.75 & $<0.0001$ \\
\hline & $p_{1}$ & 0.137606 & 0.0354 & 3.89 & 0.0001 \\
\hline & $p_{2}$ & 0.713357 & 0.0212 & 33.63 & $<0.0001$ \\
\hline
\end{tabular}

Fang (2000)'s compatible volume equation:

$$
V=0.0004 \cdot\left(d b h^{1.922847} \cdot h^{1.097805}\right)
$$

Various artificial neural network structures based on the MLP, 320 of alternatives, and BRF, 20 of alternatives, including different alternatives for the numbers of neuron and activation functions were evaluated to determine the best predictive ANN structures predicting the individual tree volume. In MLP for single entry volume predictions, inclu- ding $\mathrm{dbh}$ as an input variable, the best predictive results were obtained by the neural network architectures, including 9 neurons in hidden layer with the tan-sig activation function in both input layer and output layer. The best predictive finding in RBF including $\mathrm{dbh}$ as input variable was obtained by the neural network architectures, including 7 neurons in hidden layer with Gaussian activation function and identity activation function in the output layer. In double volume predictions with dbh and total height as input

Table 3. The goodness-of-fit statistics for three methods including the single and double entry volume equations, the taper equation of Fang et al. (2000) and best predictive artificial neural network models

Tabela 3. Statistika goodness-of-fit za tri metode uključujući jednoulazne i dvoulazne volumne jednadžbe, konusnu jednadžbu Fang et al. (2000) i najbolje predvidive modele umjetne neuralne mreže

\begin{tabular}{|c|c|c|c|c|c|c|c|}
\hline Technique/ Tehnika & $\begin{array}{l}\text { Input variable } \\
\text { Ulazna varijabla }\end{array}$ & SSE & & MSE & RMSE & AIC & SBC \\
\hline $\begin{array}{l}\text { ANN based on MLP 1-9-1 } \\
\text { ANN temeljen na MLP 1-9-1 }\end{array}$ & $\begin{array}{c}\text { dbh } \\
\text { Prsni promjer }\end{array}$ & 2.7763 & 0.9339 & 0.00910 & 0.0954 & -823.25 & -1421.81 \\
\hline $\begin{array}{l}\text { ANN based on RBF 1-7-1 } \\
\text { ANN temeljen na RBF 1-9-1 }\end{array}$ & $\begin{array}{c}\text { dbh } \\
\text { Prsni promjer }\end{array}$ & 3.5419 & 0.9157 & 0.01161 & 0.1078 & -748.97 & -1353.25 \\
\hline $\begin{array}{l}\text { Single volume equation } \\
\text { Jednoulazna volumna jednadžba }\end{array}$ & $\begin{array}{c}\text { dbh } \\
\text { Prsni promjer }\end{array}$ & 3.8539 & 0.9082 & 0.01264 & 0.1124 & -723.23 & -1327.51 \\
\hline $\begin{array}{l}\text { ANN based on MLP 2-15-1 } \\
\text { ANN temeljen na MLP 2-15-1 }\end{array}$ & $\begin{array}{c}\text { dbh } \\
\text { total height } \\
\text { Prsni promjer } \\
\text { Ukupna visina }\end{array}$ & 0.8354 & 0.9801 & 0.00274 & 0.0523 & -579.55 & -1788.11 \\
\hline $\begin{array}{l}\text { ANN based on RBF 2-9-1 } \\
\text { ANN temeljen na RBF 2-9-1 }\end{array}$ & $\begin{array}{l}\text { dbh } \\
\text { total height } \\
\text { Prsni promjer } \\
\text { Ukupna visina }\end{array}$ & 2.6344 & 0.9373 & 0.00864 & 0.0929 & -229.26 & -1437.82 \\
\hline $\begin{array}{c}\text { Double volume equation } \\
\text { Dvoulazna volumna jednadžba }\end{array}$ & $\begin{array}{l}\text { dbh } \\
\text { total height } \\
\text { Prsni promjer } \\
\text { Ukupna visina }\end{array}$ & 2.0293 & 0.9517 & 0.00665 & 0.0816 & -918.85 & -1523.13 \\
\hline $\begin{array}{c}\text { Taper equation } \\
\text { of Fang et al. (2000) } \\
\text { Taperova jednadžba } \\
\text { od Fang (Fang et al. 2000) }\end{array}$ & $\begin{array}{l}\text { dbh } \\
\text { total height } \\
\text { Prsni promjer } \\
\text { Ukupna visina }\end{array}$ & 3.4715 & 0.9173 & 0.01138 & 0.1067 & -755.10 & -1359.38 \\
\hline
\end{tabular}


variables, the neural network architecture of MLP with 15 neurons in hidden layer with the exponential activation function in both input layer and output layer resulted in best predictive volume values. The best satisfactory results in RBF including dbh and total height as input variables were obtained by the neural network architectures, including 9 neurons in hidden layer with Gaussian activation function and identity activation function in the output layer. Table 3 presented the comparative results for prediction methods, including the single and double entry volume equations, the Fang (2000)'s compatible volume equation and best predictive artificial neural network models based on the values of goodness-of-fit statistics such as SSE, AIC, SBC, RMSE, MSE and. From these fitting statistics, SSE was 2.7763 and 3.8539 for single entry volume predictions and 0.8354 and 3.4715 for double entry volume predictions; was 0.9082 and 0.9339 for single entry volume predictions and 0.9173 and 0.9801 for double entry volume predictions; MSE was 0.00910 and 0.01264 for single entry volume predictions and 0.00274 and 0.01138 for double entry volume predictions; RMSE was 0.0954 and 0.1124 for single entry volume predictions and 0.0523 and 0.1067 for double entry volume predictions; AIC was -823.25 and -723.23 for single entry volume predictions and -918.85 and -229.26 for double entry volume predictions: SBC was -1421.81 and -1327.51 for single entry volume predictions and -1788.11 and -1359.38 for double entry volume predictions. On the basis of the goodness-of-fit statistics, the ANN-based on MLP 1-9-1 including dbh as an input variable for single entry volume predictions showed better fitting ability with SSE (2.7763), (0.9339), MSE (0.00910), RMSE (0.0954), AIC (-823.25) and SBC (-1421.81) than that by the other studied volume methods including dbh as an explanatory variable. For double entry volume predictions including $\mathrm{dbh}$ and total height as input variables, ANN based on MLP 2-15-1 resulted in better fitting statistics with SSE (0.8354), (0.9801), MSE (0.00274), RMSE (0.0523), AIC (-579.55) and SBC (-1788.11).

In figure 2 , the residuals against predicted volume obtained by single entry volume equation (a), ANN based on MLP 1-9-1 (b) and ANN based on RBF 1-7-1 (c) were presented. In figure 3 , it was showed that the residuals against predicted volume obtained by double entry volume equation (a), Fang (2000)'s compatible volume equation (b), ANN based on MLP 2-15-1 (c) and ANN based on RBF 2-9-1 (d). It is seen that ANN based on MLP 1-9-1 (Fig. 2b) and ANN based on MLP 2-15-1 (Fig. 3c) presented better predictive results than others and there are no serious failure of homoscedasticity, violations of the assumption of the constant variance in predictions obtained by the ANN based on the MLP.

Further, analyze were performed to evaluate the best predictive ANN based on MLP 1-9-1 for single-entry volume predictions and ANN based on MLP 2-15-1 for double-entry volume predictions. These validation processes were realized with the analysis of the difference between observed and predicted tree volume values (residual values) based on
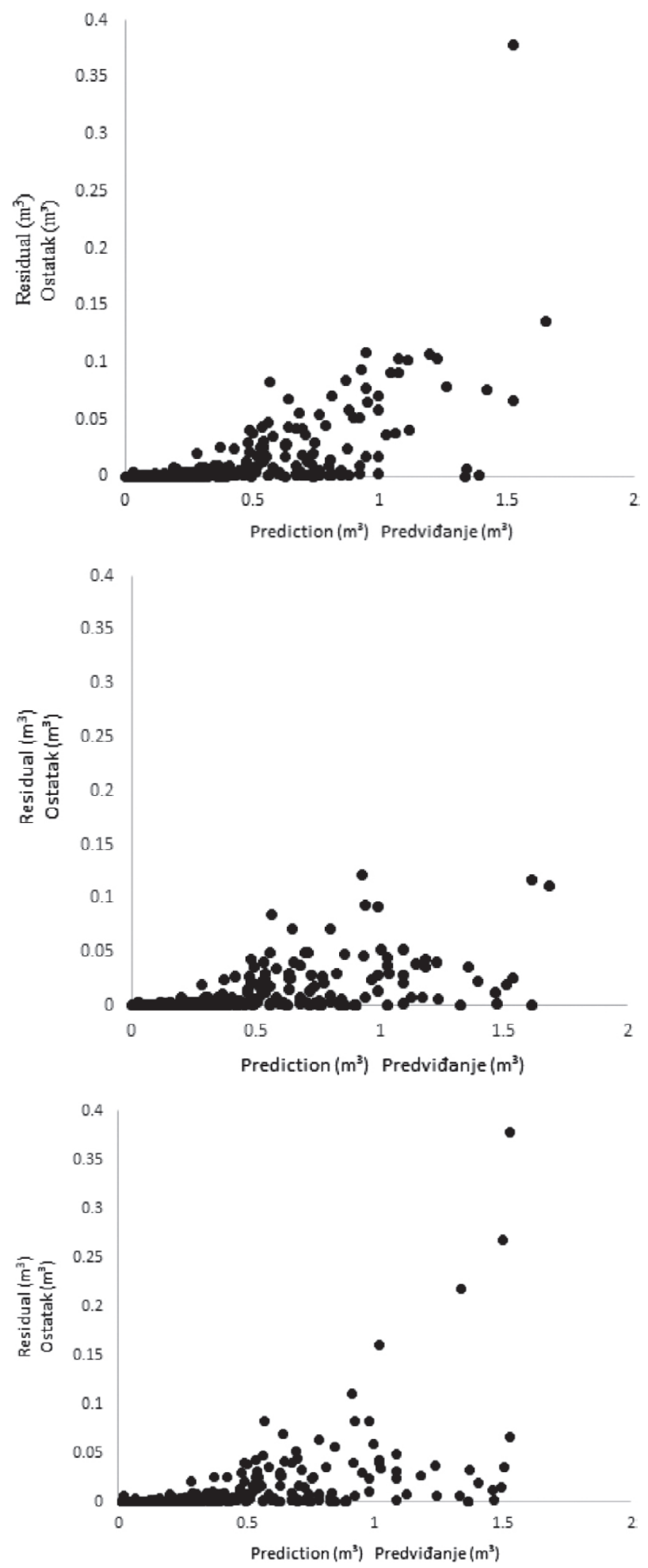

Figure 2. The residuals against predicted volume obtained by single entry volume equation (a), ANN based on MLP 1-9-1 (b) and ANN based on RBF 1-7-1 (c)

Slika 2. Razlika od predviđenog volumena dobivenog jednoulaznom volumnom jednadžbom (a), ANN temeljen na MLP 1-9-1 (b) i ANN temeljen na RBF 1-7-1 (c) 

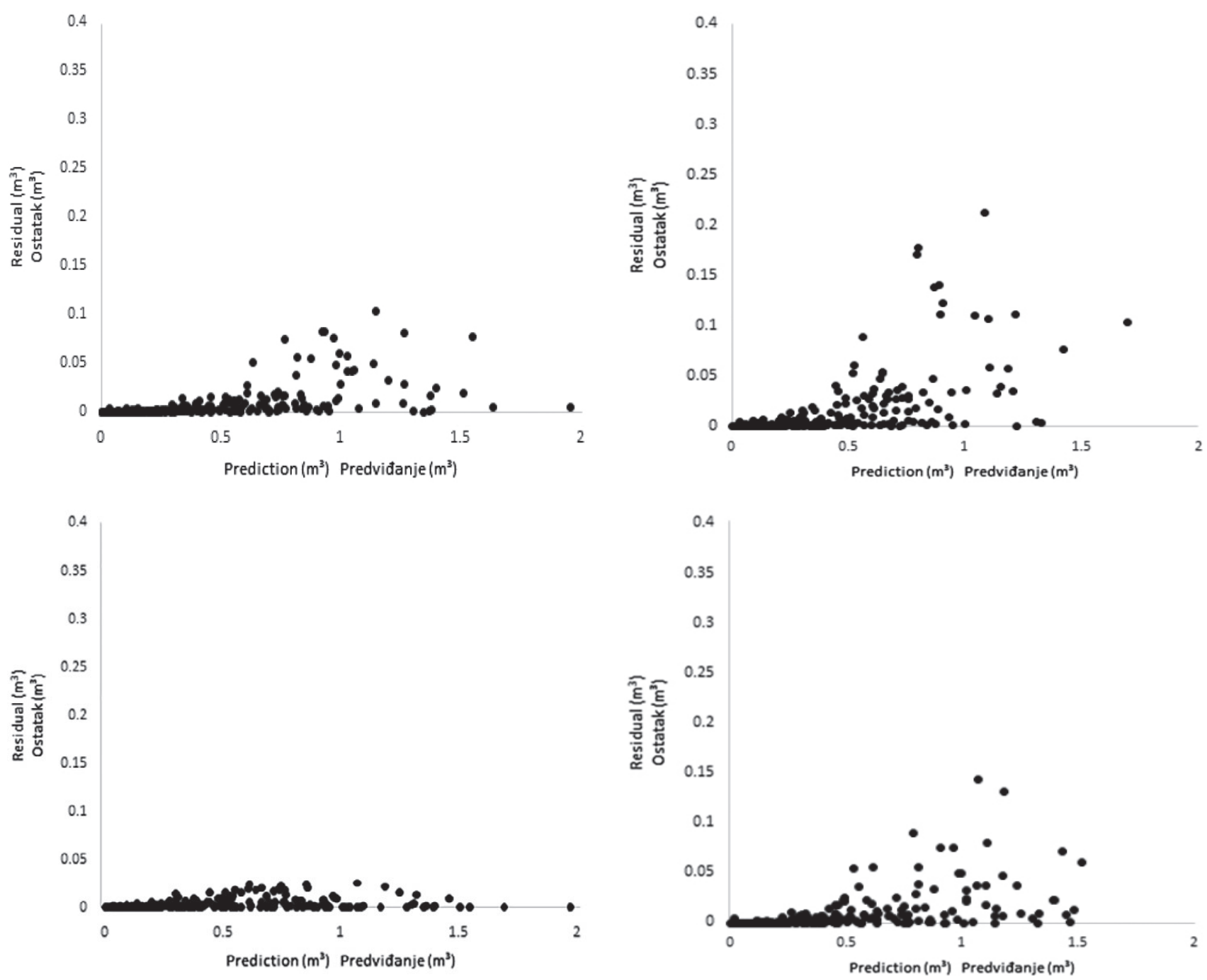

Figure 3. The residuals against predicted volume obtained by double entry volume equation (a), Fang (2000)'s compatible volume equation (b), ANN based on MLP 2-15-1 (c) and ANN based on RBF 2-9-1 (d)

Slika 3. Razlika od predviđenog volumena dobivenog dvoulaznom volumnom jednadžbom (a), kompatibilna volumna jednadžba - Fang (2000) (b) temeljena na MLP 2-15-1 (c) i ANN temeljena na RBF 2-9-1 (d).

the t-paired test evaluating null hypothesis of a mean prediction residual equal to zero including validation data set, 54 sample trees. The results for t-paired test show that the mean residuals predicted from ANN based on MLP 1-9-1 for single-entry volume predictions are not significantly different from zero, $t$ value $=-0.364, p=0.718>0.05$. Also, the mean residuals predicted from ANN MLP 2-15-1 for double-entry volume predictions are not significantly different from zero, $\mathrm{t}$ value $=0.559, \mathrm{p}=0.578>0.05$

\section{DISCUSSION RASPRAVA}

In this study, it was aimed to obtain the individual volume predictions of Crimean Black Pine in Çankırı Forests by using Artificial Neural Network Models. Also, the single and double entry-volume equations and the Fang et al. (2000)'s compatible volume equation based on the classical and traditional methods were used to acquire these tree volume predictions. The single-entry volume equation accounted for about $90.82 \%$ of the total variance in volume predictions, however, the best predictive ANN based on MLP 1-9-1 and ANN based on RBF 1-7-1 presented about 93.37 $\%$ and $91.57 \%$ of explanatory at the total variance of volume predictions, respectively. To include dbh and height as independent in tree volume predictions, the double-entry volume equations and the Fang (2000)'s compatible volume equation accounted for about $95.17 \%$ and $91.73 \%$ of the total variance in volume predictions, respectively. The ANN-based on MLP 2-15-1 and ANN based on RBF 2-9-1 including dbh and height as input variables presented the best predictive results including about $98.01 \%$ and 93.73 $\%$ of the total variance in volume predictions, respectively.

The principal purpose of this study was to reveal the usability of prediction methods based on the Artificial Neural 
Network models in individual tree volume predictions. As evaluated some goodness-of-fit statistics including SSE, AIC, SBC, RMSE, MSE and $\mathrm{R}_{\text {adj }}^{2}$ based on the amounts and distributions of predictions' residual, it can be concluded that the ANNs can be utilized for the prediction of individual tree volumes. Furthermore, better predictive individual volume predictions can be achieved by the use of ANN models with respect to single and double entry volume equations and compatible volume equation classical analysis. However, not being able to supply adequate samples for certain data ranges in the training of ANNs may cause adverse results, such as failing to ensure expected volume growth laws. For example, sampling large-diameter trees from low site quality will provide short tree samples, as a result of which increasing diameters could represent volume reduction in the samples. As the ANN structure provides flexible estimations, in parallel with this change in the data, it may indicate a decreasing volume trend with single input volume estimations based on dbh upon afterward a certain diameter level. Estimations provided by ANN structures depend, to a great extent, on the data structures used to train the network. If adequate and balanced sampling cannot be provided, these estimations will be negatively affected in terms of ensuring growth legalities.

Successful volume predictions of the ANN models for Crimean Black Pine trees may be attributed to ANN's success in modeling non-linear trend development. While developing regression models, it is checked whether they meet certain basic statistical assumptions (standard distribution and homogeneity of error variances, no correlation between errors, autocorrelation, no correlation between independent variables), which is not the case for ANN. It is because regression models are able to provide successful estimations in which such statistical assumptions have been realized, while the estimations provided by ANNs do not depend on the realization of those assumptions. In this sense, as well as their success in volume estimations, ANNs also have the advantages owing to the fact that they do not depend on statistical assumptions.

However, a significant issue that must be addressed, based on the results of the estimations for the studies to be conducted with ANNs, is the determination of a successful ANN structure among the various ANN structures that have different network algorithm and numbers of neurons. Providing certain estimations on trees and stands using ANN, an artificial intelligence application is a new method, and studies are required to determine which ANN structures will be able to provide successful estimations. In this study, ANN based on MLP 1-9-1 for single entry volume predictions including dbh as an input variable and ANN based on MLP 2-15-1 for double entry volume predictions including dbh and height as input variable provided more predictive results than other ANN structures. Nevertheless, the successes of prediction for different ANN structures should be analyzed and prominence should be given to studies conducted to determine ANN structures providing the best estimations. Conformity of the estimations provided by ANN structures with growth laws, regarding the growth trends of trees, should be assessed, which is another issue that must be approached with caution.

\section{REFERENCES}

\section{LITERATURA}

- Ashraf, M. I., Z. Zhao, A. Bourque, D.A. MacLean, F. Meng, 2013: Integrating biophysical controls in forest growth and yield predictions generated with artificial intelligence technology, $\mathrm{Ca}$ nadian Journal of Forest Research, 43, 1162-1171.

- Atkinson, P.M., A.R. Tatnall, 1997: Introduction: neural networks in remote sensing, Int. J. Remote Sens. 18(4): 699-709.

- Avery, T.E., H.E. Burkhart, 2002: Forest measurements, 5th ed. New York: McGraw-Hill, 456 p.

- Bolat, F., 2015: Predictions for Oriental beech tree heights based on the artificial neural network in Kestel forests, The $10^{\text {th }}$ International Beech Symposium, 1-6 September 2015, Kastamonu, Safranbolu, TURKEY.

- Bhering, L.L., V.S. Junqueira, L.A. Peixoto, C.D. Cruz, B.G. Laviola, 2015: Comparison of methods used to identify superior individuals in genomic selection in plant breeding, Genet Mol Res,14(3):10888-10896.

- Binoti, M.L.M.S, D.H.B. Binoti, H.G. Leite, 2013: Aplicação de redes neurais artificiais para estimação da altura de povoamentos equiâneos de eucalipto, Rev. Arvore, 37(4):639-645.

- Buğday, E., 2018: Application of Artificial Neural Network System Based on ANFIS Using GIS for Predicting Forest Road Network Suitability Mapping, Fresenius Environmental Bulletin, Volume 27 - No. 3/2018 pages 1656-1668.

- Clark, A., R.A. Souther, B.E. Schlaegel, 1991: Stem profile equations for southern tree species, USDA For. Serv. Res. Pap. SE282.

- Clutter, J.L., J.C. Fortson, L.V. Pienaar, G.H., Brister, R.L. Bailey, 1983: Timber management: A quantitative approach, John Wiley \& Sons, Inc., $333 \mathrm{p}$.

- Corral-Rivas, J.J., U. Diéguez-Aranda, S. Corral, F. Castedo, 2007: A merchantable volumen system for major pine species in El Salto, Durango (Mexico), For. Ecol. Manage., 238: 118-129.

- Crecente-Campo, F., M. Tomé, P. Soares, U. Diéguez-Aranda, 2010: A generalized nonlinear mixed-effects height-diameter model for Eucalyptus globulus L. in northwestern Spain, Forest Ecology and Management, 259, 943-952.

- Demuth, H., Beale, M., 2001: Neural network toolbox For use with Matlab', User's Guide, V4, 25.

- Diamantopoulou, M. J., 2005: Predicting fir trees stem diameters using Artificial Neural Network models, Southern Forests: a journal of Forestry Science, 205, 39-44.

- Diamantopoulou, M.J., 2006: Tree-Bole Volume Estimation on Standing Pine Trees Using Cascade Correlation Artificial Neural Network Models, Agricultural Engineering International: the CIGR ejournal. Manuscript IT 06 002, Vol. VIII. 
- Diamantopoulou, M. J., R. Özçelik, 2012: Evaluation of different modeling approaches for total tree-height estimation in the Mediterranean Region of Turkey, Forest Systems, 21, 3, 383-397.

- Diamantopoulou, M. J., R. Özçelik, F. Crecente-Campo, Ü. Eler, 2015: Estimation of Weibull function parameters for modeling tree diameter distribution using least squares and artificial neural networks methods, Biosystem engineering, 133, 33-45.

- Diéguez-Aranda U., F. Castedo, J.G. Álvarez , A. Rojo, 2006: Compatible taper function for Scots pine plantations in Northwestern Spain, Can. J. For. Res., 36: 1190-1205.

- Doğan, S., E. Buğday, 2018: Modeling of Temporal and Spatial Changes of Land Cover and Land Use by Artificial Neural Networks: Kastamonu Sample, Journal of Bartin Faculty of Forestry, 20 (3): 653-663, doi: 10.24011/barofd.467974.

- Elmas, Ç., 2003: Artificial Neural Networks (Theory, Architecture, Education, Practice) Yapay Sinir Ağları (Kuram, Mimari, Egitim, Uygulama), Seçkin Publishing, Ankara, TURKEY, p.2237.

- Ercanl, İ., S. Keleş, M. Şenyurt, A. Günlü, F. Bolat, K. Kurt, 2014: Development of Compatible Body Diameter and Body Volume Equations for Crime pine stands Shaped Within the Limits of Tarsus Forest Enterprise with Mixed Effect Modeling Approach, TUBITAK Quick Support Projects Program. Projeckt number: TOVAG-113O729.

- Ercanl, İ., A. Kahriman, F. Bolat, 2015: Applications of an artificial neural network for predicting the relationships between height and age for oriental beech, The $10^{\text {th }}$ International Beech Symposium, 1-6 September 2015, Kastamonu, Safranbolu / TURKEY

- Ercanl, İ., A. Günlü, M. Şenyurt, F. Bolat, A. Kahriman, 2016: Artificial neural network for predicting stand carbon stock from remote sensing data for even-aged scots pine (Pinus sylvestris L.) stands in the Taşköprü-Şiftlik forests, $1^{\text {st }}$ International Symposium of Forest Engineering and Technologies (FETEC 2016): Forest Harvesting and Roading in Environmentally Sensitive Areas, 02-04 June 2016, 2016, Bursa, Turkey

- Esteban, L.G., F.G. Fernandez, P. de Palacios, 2009:MOE Prediction in Abies pinsapo boiss. Timber: application of an artificial neural network using non-destructive testing, Computers, and Structures, 87, 1360-1365.

- Fang, Z., B.E. Borders, R.L. Bailey, 2000: Compatible volumetaper models for loblilly and slash pine based on a system with segmented-stem form factors, Forest Science, 46, 1, 1-11.

- Fausett, L.,1994: Fundamentals of neural networks architectures, Algorithms, and applications, Prentice Hall, USA.

- Firat, F., 1973: Dendrometry. $4^{\text {th }}$ edition1, Istanbul University Forest Faculty, Publishing number: 1800, Istanbul, TURKEY.

- Firat, M., 2002: Determination of Depth of Convection around Bridge Legs Placed in Linear and Curved Rivers by Artificial Neural Networks, . Phd thesis. Pamukkale Natural And Applied Science.

- Frrat, M., M. Güngör, 2004: Determination of Carried Suspended Sediment Concentration and Amount by Artificial Neural Networks, IMO Technical Journal, 15, 3, 3267- 3282.

- Gal, J., I.E. Bella, 1994: New stem taper functions for 12 Saskatchewan timber species, Nat. Resour. Can., Can. For. Serv., Northwest Region, North. For. Cent., Edmonton, Alta., Canada, Inf. Rep. NOR-X-338.
- Gorgens, E.B., H.G. Leite, H.N. Santos, J.M. Gleriani, 2009: Estimação do volume de árvores utilizando redes neurais artificiais, Rev. Arvore 33(6):1141-1147 gorgens.

- Gurney, K., 1999: An introduction to neural networks, UCL Press, UK.

- Jiang, L., J.R. Brooks, J. Wang, 2005: Compatible taper and volüme equations for yellow-poplar in West Virginia, Forest Ecology and Management, 213, 399-409.

- Kalıpsiz, A., 1999: Dendrometry. Istanbul University Forest Faculty Publishing number:3194/354, İstanbul.

- Kapucu, F., H. Yavuz, A.U. Gül, N. Misır, 2002: Production and management principles of chestnut stands, Tubitak TAGTOG TARP, Projeckt number 2229.

- Kurup P. U., N.K. Dudani, 2002: Neural Networks for Profiling Stress History of Clays from PCPT Data. Journal of Geotechnical \& Geoenvironmental Engineering, 128, 7, 569-580.

- Li, R., A.R. Weiskittel, 2010: Comparison of model forms for estimating stem taper and volume in the primary conifer species of the North American Acadian region, Annals Forest Science, Vol.67; pp.302-317.

- Max, T.A. , H.E. Burkhart, 1976: Segmented polynomial regression applied to taper equations, For. Sci. 22(3):283-289.

- Miguel, E.P., F.C.M. Mota, S.J. Teo, R.G.M. Nascimento, F.A. Leal, R.S. Pereira, A.V. Rezende, 2016: Artificial intelligence tools in predicting the volume of trees within a forest stand, African Journal of Agricultural Research, v. 11, n. 21, p. 1914-1923.

- Nasr, G. E., E.A. Badr, C. Joun, 2003: Backpropagation neural networks for modeling gasoline consumption. Energy Conversion and Management, 44 (6), 893-905.

- Orhunbilge, N., 2002: Applied Regression and Correlation Analysis, Istanbul University Faculty of Management publishing, 2nd edition, Istanbul, Turkey.

- Özçelik, R., M.J. Diamantopoulou, H.V. Wiant, J.R. Brooks, 2010: Estimating tree bole volume using artificial neural network models for four species in Turkey, Journal of Environmental Management, 91, 3, 742-753.

- Özçelik, R., M.J. Diamantopoulou, H.V. Wiant, J.R. Brooks, 2010: Estimating tree bole volume using artificial neural network models for four species in Turkey, Journal of Environmental Management, 91, 3, 742-753.

- Özcelik, R., M.J. Diamantopoulou, F. Crecente-Campo, Ü. Eler, 2013: Estimating Crimean juniper tree height using nonlinear regression and artificial neural network models. Forest Ecology and Management, 306, 52-60

- Özcelik, R., M.J. Diamantopoulou, J.R. Brooks, 2014: The use of tree crown variables in over-bark diameter and volume prediction models. iForest-Journal of Biogeosciences and Forestry, 7:132-139.

- Pompa G.M., J.J.R. Corral, M.A. Díaz V, M.S. y Martínez, 2009: Función de ahusamiento y volumen compatible para Pinus arizonica Engelm., en el Suroeste de Chihuahua, Revista Ciencia Forestal en México, 34(105):119-136.

- Quiñonez-Barraza, G., los Santos-Posadas, D., Héctor, M., Álvarez-González, J.G., Velázquez-Martínez, A.,2014: Sistema compatible de ahusamiento y volumen comercial para las principales especies de Pinus en Durango, México Agrociencia 48, 553-567.

- Sanquetta C.R., A. Behling, A.P. Dala Corte, M.S. Ruza, A. Simon, J.F.B. São José, 2014: Relação hipsométrica em inventários 
pré-corte em povoamentos de Acacia mearnsii De Wild. Científica 42(1):80-90.

- Soares, F.A.A.M.N, E.L. Flôres, C.D.E.L. Cabacınha, G.A. Carrijo, A.C.P. Veiga, 2011: Recursive diameter prediction and volume calculation of eucalyptus trees using Multilayer Perceptron Networks, Computers, and Electronics in Agriculture, v.78, n.1,p. 19-27.

- Silva, M.L.M., D.H.B. Binoti, J.M. Gleriani, H.G. Leite, 2009: Ajuste do modelo de Schumacher e Hall e aplicação de redes neurais artificiais para estimar volume de árvores de eucalipto, Rev. Arvore, 33(6):11331139.

- Şentürk, N., 1997: Arrangement of ash (Fraxinus angustifolia Wahl. subps.Oxycarpa (Bieb.ExWilld.)Franco\&RochaAfonso) body volume and wood volume tables, . Phd thesis. Pamukkale Natural And Applied Science.

- Reed, D.D., E.J. Green, 1984: Compatible stem taper and volüme ratio equations, For. Sci. 30(4):977-990.

- Tang, X., C. Pérez-Cruzado, L. Fehrmann, J.G. ÁlvarezGonzález, Y. Lu, C. Kleinn, 2016: Development of a Compatible Taper Function and Stand-Level Merchantable Volume Model for Chinese Fir Plantations, PLoS ONE 11(1): $1-15$
- Topçu, İ.B., M. Sarıdemir, 2008: Prediction of Compressive Strength of Concrete Containing Fly Ash Using Artificial Neural Networks and Fuzzy Logic. Computational Materials Science, 41, 305-311.

- Van Laar, A., A. Akça, 2007: Forest mensuration, Springer, Dordrecht, 383 pp.

- Wiant, H.V.Jr., G.B. Wood, T.G. Gregoiıre, 1992: Practical guide for estimating the volume of a standing sample tree using either importance or centroid sampling, Forest Ecology, and Management, 49, 333-339.

- Yavuz, H., 1995: Compatible and incompatible trunk diameter models, Karadeniz Technical University Faculty of Forestry spring seminars, faculty publication number:49, 101106.

- Yavuz, H., 1999: Volume Functions and Volume Tables for Crimean pine in Taşköprü Region, Turkish Journal of Agriculture and Forestry, 23, 1181-118.

- Yavuz, H., O.E. Sakıcı, 2002: Scientific and practical examination of body profile models, Conceptual expansions and new targets in forest management symposium, Istanbul, Turkey, p.233-241.

\section{SAŽETAK}

Cilj ovog rada je usporediti modele umjetne neuralne mreže (ANN) za predviđanje pojedinih drvnih volumena krimskih borova u šumama Çankirija. Jednoulazne i dvoulazne jednadžbe i kompatibilna volumna jednadžba Fang et al. (2000) temeljena na klasičnim i tradicionalnim metodama primijenjena je na 360 krimskih borova u cilju dobivanja ovih drvnih volumena. Kako bi se odredila najbolja alternativna metoda za predviđanje ANN modela, ukupno je obučeno 320 treniranih mreža u višeslojnom perceptronu (MLP) i ukupno 20 treniranih mreža u arhitekturi Radial Basis Function (RBF). Na temelju statistike goodness-of-fit, ANN u smislu MLP 1-9-1 uključujući dbh kao input varijablu za jednoulazna volumna predviđanja pokazao je bolju fitting sposobnost sa SSE (2.7763), Radj2 (0.9339), MSE (0.00910), RMSE (0.0954), AIC (-823.25) i SBC (-1421.81) nego onaj u ostalim proučavanim volumnim metodama koje uključuju dbh kao eksplanatornu varijablu. Za dvoulazna volumna predviđanja, što uključuju dbh i ukupnu visinu kao input varijable, ANN temeljen na MLP 2-15-1 rezultirao je boljom fitting statistikom sa SSE (0.8354), Radj2 (0.9801), MSE (0.00274), RMSE (0.0523), AIC (-579.55) and SBC (-1788.11).

KLJUČNE RIJEČI: Predviđanje drvnog volumena, umjetna neuralna mreža, krimski bor, linearna analiza regresije, šume Cankiri 